\title{
Climate change adaptation as a global public good: implications for financing
}

\author{
Mizan R. Khan ${ }^{1}$ (D) $\cdot$ Sirazoom Munira ${ }^{2}$ (D) \\ Received: 31 May 2020 / Accepted: 31 July 2021/ Published online: 24 August 2021 \\ (C) The Author(s), under exclusive licence to Springer Nature B.V. 2021
}

\begin{abstract}
Beginning as an afterthought in the UN Framework Convention on Climate Change, adaptation as an agenda has come a long way since 1992. With no ambitious mitigation, recent years have witnessed an increasing frequency of extreme climate events, including cross-border or borderless climate risks. Accordingly, the Paris Agreement frames adaptation as a global goal and global responsibility. However, financing for adaptation continues to remain extremely poor, relative to the estimated needs, even though the regime has obligatory provisions for support by developed countries. Why is this so? Why should the majority of the countries, with an insignificant contribution to causing the problem, suffer from increasing climate impacts? How can adaptation finance be enhanced at scale? As a response to these queries, the paper substantiates three claims: (1) that poor funding can be attributed to the territorial framing under the regime that conceptualizes adaptation largely as a local or national public good and, hence, the inefficacy of market mechanisms, (2) that it makes conceptual and political sense to consider adaptation as a global public good, and (3) that such a reframing should make a difference in boosting adaptation finance. In a multi-polar world with different views on adaptation finance, multilateral agencies should lead in promoting the proposed framing.
\end{abstract}

Keywords Cross-border climate risks · Adaptation · Climate finance $\cdot$ Global public goods · Polluter-pays principle

\section{Sirazoom Munira}

sirazoom.munira@northsouth.edu

Mizan R. Khan

mizan.khan@icccad.org

1 International Centre for Climate Change and Development (ICCCAD), Independent University, Bangladesh, Dhaka 1229, Bangladesh

2 Department of Environmental Science and Management, North South University, Dhaka 1229, Bangladesh 


\section{Introduction}

Adaptation to climate change has gained prominence over time on the policy agenda, though it began as an afterthought in the UN Framework Convention on Climate Change (UNFCCC). The reasons are that there is inadequate mitigation taking place globally, the frequency and magnitude of climate disasters are increasing, and the climate justice movement is strengthening (Khan and Roberts 2013). The Intergovernmental Panel on Climate Change (IPCC) Special Report on Global Warming of $1.5^{\circ} \mathrm{C}$ (2018) acknowledged that "Warming of $1.5^{\circ} \mathrm{C}$ is not considered 'safe' for most nations and poses significant risks to natural and human systems," and that "The benefits from industrialization have been unevenly distributed and those who benefited most historically also have contributed most to the current climate problem and so bear greater responsibility."

Article 3.1 of the Convention defines equity and "common but differentiated responsibilities based on respective capabilities" $(\mathrm{CBDR}+\mathrm{RC})$ as the foundational principle to share the burden of addressing climate change. But this responsibility is not reflected in mobilizing climate finance for supporting the particularly vulnerable countries (PVCs), who suffer the most from climate change. The Paris Agreement provides for this responsibility as well. The pledge by developed countries and the actual delivery of finance vary widely. Also, the issue of funding is extremely complex, particularly for adaptation, because of a lack of conceptual clarity in the regime and its accounting modality. The status of adaptation finance shows a gap in orders of magnitude between the estimated needs and the supply (UNEP 2016). Despite pledges of a balanced allocation with mitigation, adaptation commands only $21 \%$ of international public climate finance (OECD 2020), of which grants are only 20\%, the remaining being loans and non-grant instruments (Oxfam 2020).

This continued scarcity in adaptation finance is the big puzzle in adaptation politics (Khan 2014). There is agreement that climate change is global, both in its cause and effect dimensions. It is a collective action problem, so there is a built-in compulsion for addressing its "cause" through universal cooperation, as the Paris Agreement vindicates. The mitigation regime is not succeeding yet because of disagreements over sharing of responsibility among major emitters, but nobody questions the properties of restoring climate stability as a lifesupport global public good (GPG), the benefits of which are available to everyone and nobody can be excluded. Then, what about the "effect" of antecedent stock deposition of emissions, or the current undersupply of mitigation, that inflicts increasingly unbearable harm to the PVCs? Should not climate impacts be regarded as a global public bad (GPB), and hence, adaptation to cope with those bads as GPG? This article lays out the case for doing so.

Though framing of adaptation is now expanding, literature during the first two decades of climate negotiations looked at adaptation largely as a private good and local or national public good (Barrett 2008). Benzie and Persson (2019) argue that in the initial years, the then epistemic community looked at climate impacts from a narrow environmental science perspective and so the Convention codified adaptation at a local/national scale, with the predominant focus given to mitigation. They also present cases of "borderless climate risks," which may be experienced locally, but have cross-border, even global repercussions, as indirect impacts (Hedlund et al. 2018). So the framing of adaptation is being expanded by multidisciplinary thinking from national to the global level, requiring international cooperation and multi-stakeholder engagement (IPCC 2018; Dzebo and Stripple 2015; Khan 2016).

Accordingly, the norm of globalizing responsibility for adaptation has been recognized in the Paris Agreement, as a "global goal" and a "global challenge" (Articles 7.1 and 7.2). Ironically, 
there is no effort at operationalizing this norm, or in codifying it through adequate adaptation support to address the "effect" part of climate change. Herein, Gardiner's thesis of "theoretical ineptitude" (2006: 407) still persists, which manifests in undermining the agreed responsibility, and in not appreciating the spatial, temporal, or long-term dimensions of climate change. This condemns those mainly responsible to a "moral corruption." Why should the PVCs, including the least developed countries (LDCs) and small island developing states (SIDS), which contribute least to the problem, suffer the most from "imported" climate impacts (Persson 2019)?

Normative discourse contributes to issue-framing and norm building, but is not common yet in adaptation (Benzie and Persson 2019). The epistemic ambiguity in adaptation, in absence of a politically agreed definition, compounds the problem. Increasingly, the positive externalities of adaptation actions as "multi-level public goods," at domestic, transboundary, and global levels, are being articulated (Banda 2018; Khan 2014). Kaul (2017a) cogently argues that climate finance suffers from theoretical and institutional lock-in, with reliance on theories and practices that fit neither the GPG nature of climate change nor the current policymaking realities. We may recall that public goods were defined as non-excludable and non-rival in consumption almost 70 years back by Samuelson (1954), when extraterritorial pollution problems were not yet a global agenda. As adaptation is a new but contested public policy arena, our articulation is based on constructivism, that public goods as a living category are variable social constructs, in response to evolving national and global needs, as matters of policy choice.

So this paper as a normative argument addresses the theoretical inadequacy on adaptation and the conceptual and institutional lock-in on the issue, while reframing adaptation as a GPG and its likely positive implications for adaptation finance. The proposed framing as an integrative conception combines ideas from environmental economics, international law and relations, political economy, human rights, security studies, and state responsibility. With this goal, this paper substantiates three claims: (i) that inadequate adaptation finance is due to the inefficacy of market instruments and its territorial framing, that looks at adaptation only as a local or national public good; (ii) that it makes conceptual and political sense to consider adaptation as a GPG; and (iii) that framing adaptation as a GPG would make a difference by boosting public finance. What follows are three sections on the three claims, with a conclusion.

\section{Inadequate finance is due to current territorial framing of adaptation}

\subsection{Why adaptation finance remains poor}

There is still no agreed definition of climate finance, even after a quarter century of negotiations. So each developed country can decide what it counts as such, why, and whether it can be considered as "new and additional" (Weikmans et al. 2017). This contributes to widely differing estimates by agencies, for example, of the Fast Start Finance of $\$ 30$ billion, pledged at Copenhagen in 2009 as immediate delivery during 2010-2012, between 05 and $30 \%$ went to adaptation (Nakhooda et al. 2013; Buchner et al. 2019). What is more disquieting is that the overwhelming share of climate finance (76-80\%) is recycled official development assistance (ODA) (Oxfam 2012; Nakhooda et al. 2013). But under the regime provisions, climate finance is agreed to be different, as "new and additional" (Article 4.3 of the Convention). The UNEP (2016) estimates that by 2030 up to $\$ 300$ billion a year will be needed to address climate impacts. The Paris Agreement stipulates for a new global goal of fund mobilization by 2025 , keeping the $\$ 100 \mathrm{bn}$ pledged at Copenhagen as the floor (which was supposed to be reached by 2020). 
However, the OECD (2020) claims that climate finance rose by $11 \%$ in 2018 compared to 2017 , totaling $\$ 78.9$ billion, with bilateral climate finance accounting for $\$ 32.7$ billion ( $26 \%$ of ODA) and multilateral for $\$ 29.6$ billion. But Oxfam (2020) deflates this number down more than three times, showing only \$19-22 billion as climate-specific net assistance, of which \$6-7 billion is for adaptation. Over-reporting of climate relevance of supported projects and reporting loans at face value (not its grant-equivalence) causes most of this inflated estimate. In 2017-18, only an estimated $20.5 \%$ of bilateral climate finance went to LDCs and $3 \%$ to SIDS, and a majority of it was in the form of loans and non-grant instruments (Oxfam 2020), and the share of loans is increasing. In 2016-17, only $3 \%$ of the mobilized private finance was for adaptation. All these numbers speak for themselves: the Copenhagen pledge and the Paris Agreement are not being met.

The main reason behind the shortage of adaptation finance is that market instruments and private sector are not interested in addressing adaptation (except for profit-earning insurance), because adaptation largely has public good characteristics. Unlike in mitigation, there are no measurable indicators or offset benefits from adaptation. As indicated, the conventional conceptualization looks at adaptation as local, national, or at best as a regional public good (Tigre 2019). However, the private sector is active in promoting renewable energy both in developed and developing countries, which brings in mostly mitigation benefits and avoided fossil fuel energy costs, but decentralized renewable energy systems also have adaptation benefits. As mitigation anywhere brings in direct global benefits, there is a significant bias for supporting it by public, private, multilateral funding, and even by NGOs in developing countries (OECD 2020; Chan and Amling 2019).

Further, climate investments show a bias toward developed countries. Abadie et al. (2013) explain the factors behind this, as fewer risks, known investment environments, and ancillary local benefits, such as clean air and improved infrastructure. But doing more adaptation in developed countries may actually discourage them from ambitious mitigation, an early fear that now is evident. Two decades ago Michaelowa (2001) argued that more adaptation in the Global North without adequate mitigation made the Global South worse off. This was the rationale for why the UNFCCC put a single-minded focus on mitigation, with adaptation just as an afterthought. So, in the initial years, there were closet adaptationists, who feared going public (Burton 2009).

Another issue with adaptation finance is its mixing with ODA. Climate finance is obligatory for developed countries under the Paris Agreement (with the language "shall provide"), and the Convention in certain terms differentiates it as having to be "new and additional, adequate and predictable" (Article 4.3). But ODA is voluntary. However, the PVCs suffer from both development and adaptation deficits (Burton 2009; Fankhauser and Mcdermott 2014). This allows some developed countries the wiggle room to blur the qualitative difference between the two. While ODA is declining (Kenny 2020), climate finance is increasing (OECD 2020), significantly displacing ODA. Now, $26 \%$ of ODA is used as climate finance, an increase of $37 \%$ compared to 2014 (Development Tracker 2020). But ODA is vitally needed for the provision of basic services for the poor and for infrastructure development. More discussion on adaptation vs. development will follow.

\subsection{Lacuna in conceptualizing adaptation}

Khan and Roberts (2013) analyze the rise of adaptation agenda from its unsteady foundation in the 1990s, arguing that three factors drove this shift: (i) an increase in climate disasters in 
recent years, which sharpened the cognitive frame of climate justice; (ii) no ambitious mitigation, so to mollify developing country sentiments, industrial countries made concrete proposals of climate finance in Copenhagen; and (iii) inclusion of the agenda of Loss and Damage (L\&D), adding a new momentum in adaptation policy. But this ascent is not translated into adequate, new, additional, and predictable finance.

As mentioned, the initial impact-focused vulnerability perspective contributed to adaptation actions being codified as local or national. Article 3.3 of the Convention stipulates for taking precautionary measures, and that "measures to deal with climate change should be costeffective so as to ensure global benefits at the lowest possible cost." This provision stood as a disincentive to adaptation finance, because adaptation was judged from a narrow economic perspective as not contributing to global benefits, with the properties of non-excludability and non-rivalness in consumption (explained before).

But the global premise of adaptation as an additional burden for development in the PVCs presents "risks" from a biophysical change in the atmosphere, rather than socio-economic factors that make people vulnerable to these changes. And these factors are connected to existing development needs and contexts. According to this perspective, adaptation needs emerged from non-mitigation, resulting in an "impacts-based" approach to climate change risk, which is seen as requiring an external scientific and technical solution (Ayers 2011).

It is important to note the dissimilar interpretations of how neoliberal economics, the foundational base of the climate regime, looks at adaptation. One group argues that given the direct climate change impacts and adaptation benefits being local, national, or at best regional, adaptation does not constitute a GPG (Zedillo 2008), presenting a less compelling case for global cooperation. Further, adaptation concerns present a poor case for market instruments (Driesen 2009). These ideas draw their strength from Article 3.3 of the UNFCCC, cited above.

The other group argues differently, that economics should internalize the externality of emissions through the polluter-pays-principle, and that this is the most effective way forward (Stiglitz 2012; Young 2010; Khan 2015). The climate regime reflects more of this philosophy under the principle of equity and differentiated responsibility based on respective capability (Article 3.1 of the Convention), but "constructed ambiguity" is used as a strategic resource by those with power (Best 2008). The opposition to the polluter-pays-principle and the spatial disconnect between the main causers and sufferers, explain Gardiner's "theoretical ineptitude" and moral storms around climate vulnerability and adaptation. We now turn to reconceptualizing adaptation, to correct these lacunae.

\section{It makes conceptual and political sense to consider adaptation as a GPG}

\subsection{Conceptualizing adaptation as a GPG}

Climate change is the most diabolically complex problem the world faces today. An inherent feature of climate change is its global dimension, both in its cause and effect: diffuse sources of emissions create differing impacts across regions. Accumulated emissions of yesteryears are mixing with the increasing emissions of today. To stay within the remaining carbon budget consistent with the Paris goal of $1.5^{\circ} \mathrm{C}$, the world has to reduce carbon emissions by $33-50 \%$ by 2030 (IPCC 2018). Against this aspiration, emissions keep rising, reaching $59 \mathrm{GtCO}_{2} \mathrm{e}$ in 2019 (UNEP 2020). 
So the sink capacity as a global commons or common pool resources (CPRs) is already under severe stress. Climate change presents the greatest market failure (Stern 2008), which externalizes the emissions cost. As a result, atmospheric sink capacity has become rival, and this rivalness in public good is argued as a source of power for those who are not willing to replenish it (DeSombre 2000). The continued under-pledges of mitigation in the NDCs reflect this, that even $100 \%$ compliance of the pledges will push to a $3{ }^{\circ} \mathrm{C}$ temperature rise (UNFCCC 2016). But nobody questions the basic properties of mitigation as a GPG.

The irony is that the effects of undersupply of mitigation as increased disasters are not regarded as a GPB. Even if it is, adaptation to those effects is not considered a GPG. The Netherlands Environmental Assessment Agency (2011) rightly argues that GPBs should be countered by GPGs. Though some scholars theorize the normative or equity aspects of adaptation, none but Gardiner (2006) attempts to conceptualize climate impacts as a result of failed mitigation. Another exception is Vanderheiden's expansive idea of adaptation tending to plug the conceptual gap a little: "Adaptation intervenes in the causal chain between climate change and human harm, allowing the former but preventing the latter, but when this is not possible, a third category of compensation costs must be assigned in order to remedy failed mitigation ...so adaptation shall be understood to include prevention of harm as well as ex post compensation to it" (Vanderheiden 2011: 65). So the no-harm rule and ex post compensation should be considered as obligatory, as in the EU (Khan 2015). Birdsall and de Nevers (2012:1) rightly argue that adaptation finance "is better thought of as a financial transfer based on the 'causal responsibility' of richer to poorer countries for the disproportionate costs to the poor ..." These costs are the result of "imported" impacts from beyond their borders (Persson 2019). Benzie and Persson (2019) demonstrate how borderless climate risks, both direct and indirect, challenge the territorial framing of adaptation. So they argue for globalizing adaptation governance, while appreciating the notion of adaptation as a GPG.

Together with this expansive framing, the works of Kaul et al. (1999, 2003) contain expanded interpretations of GPGs. They argue that a globalized world with both goods and bads, demands a new understanding of GPGs, different from the neoclassical, national territory-bounded framing. Kaul et al. (1999: 16) defined GPGs as "goods whose benefits are strongly universal in terms of countries (i.e., covering more than one group of countries), people (i.e., accruing to several, preferably all, population groups), and generations ..." Further, they classified GPGs into three groups (p.453): (a) global natural commons, such as high seas and the atmosphere; (b) global human-made commons, such as global networks, knowledge, and international regimes; and (c) global policy outcomes and conditions, such as peace, security, and financial stability. Thus, restored climate stability, the increased number of knowledge networks, multi-disciplinary IPCC science, adaptation actions benefitting the majority of countries and populations, which contribute to poverty reduction, resilient development and peace building fully qualify as GPGs. Magnan and Ribera (2016) view adaptation as a GPG, as climate change has potential to displace peoples or create new global public health challenges, and these can only be addressed through international cooperation.

Another group of scholars (Wuyts et al. 1992; Remling 2018) argue that public goods are socially defined and socially constructed in response to public needs, rather than containing the innate characteristics as non-excludability and non-rivalness. Kaul et al. (2003) also argue that publicness or privateness are social constructs, as matters of policy choice to evolving needs. Further, adaptation and its financing are an emerging field of public policy, where politicalsocial dynamics matter. Central to this articulation is social constructivism and normative political theory (Khan 2016), which argue that the questions of norms, morality, and justice are 
not external, but very much intrinsic to interactions among states in the twenty-first century (Okereke 2010).

Actually, social science research is often conducted within an interpretive paradigm, which focuses on the meaning people ascribe to various aspects of their lives (Rayner and Malone 1998). This perspective argues that reality is subjective and that "truth" in social life is a construct reflecting our own experiences - historical, cultural, and experiential. In International Relations, constructivists emphasize a shift away from neoclassical, rationalist, and interestbased accounts to factor in the role of knowledge, norms, and values in shaping positions of nation-states, which are guided not just by material power, but also by discursive power and ideational elements (Haas et al. 2003).

Along this line, the framing of adaptation as a GPG, though gradually inching forward, makes it a contested concept (Hall and Persson 2018). For example, Long and Woolley (2009) argue that such an interpretation of GPGs is rhetorically effective, but poorly defined, lacking in conceptual clarity. Here, we take on refuting the critiques of adaptation as a GPG. First, the initial understanding of public goods under neoclassical framing by Samuelson (1954) was national, territory-bounded (Sandmo 2006), as in those days no global externality or borderless climate risks were on the global agenda. Cross-border externality problems now represent a group of GPBs, requiring their collective internalization into national and global policy processes. Even the widening disparity and concentration of poverty in middle-income countries are now viewed by some as a GPB, warranting collective solution (Sumner 2012).

Kaul et al. (1999:12, 103) argue that poverty alleviation could be a GPG if it contributes to conflict prevention, peace, and environmental protection; even social justice that promotes productivity of the poor, and hence peace and stability, is regarded as a GPG. Adaptation emphatically fits into this category. Kaul (2017b) also argues that enhanced provision of GPGs can contribute to poverty reduction, if it is not financed by ODA. Along this line, we argue that providing restitution for climate justice through adaptation support in the PVCs does contribute to poverty reduction, global peace, and harmony. Actually, adaptation actions bring in a quadruple dividend: avoided losses, economic benefits through increasing productivity, and social and environmental benefits. The World Bank estimates that the added burden of Covid19 will push an additional 88-115 million people into extreme poverty in 2020, with the total rising to as many as 150 million by 2021 (World Bank 2020). So supporting a series of local and national resilient societies becomes a GPG, measurably enhancing global harmony, peace, and security. The Global Commission on Adaptation calculated that every US dollar invested in building climate resilience could result in between $\$ 2$ and 10 in net economic benefits (2019). Such investments in individual countries certainly have spill-over benefits beyond one's border.

Second, ambitious mitigation brings in the most adaptation benefits in the form of avoided losses and damages, as Vanderheiden (2011) argues; this is not taking place, so adaptation must include prevention of harm and ex post compensation for unavoidable L\&D. The argument is that inflicting harm on a person or a country without due diligence is a culpable action, and hence liable for paying compensation (Verheyen 2005; Farber 2007). Such payment actually is the application of the Polluter Pays Principle ex post. Though Decision 1/CP.21 (para 51) forecloses the claims of liability under L\&D, it is not contained in Article 8 of the PA. Also, it does not stop CSOs or citizens from suing the polluters, as is happening worldwide, in the EU and the USA.

Third, the centuries-old Westphalian lens of sovereignty cannot deal with emerging GPGs (Nordhaus 2005), and a new type, what Kaul (2013) calls smart power or pooled sovereignty, 
is warranted. Together, the most fundamental lesson of economics - internalization of emissions externalities - must be applied. So, as Kaul (2017a), a shift away from the lock-in to conventional theorizing of GPGs is warranted, toward a public economics that truly represents the global policy concerns like climate change.

Fourth, funding for adaptation brings in both direct and indirect global benefits through many different pathways (Table 1), such as, bio-physical (shifts in eco-systems/species range, transboundary river basins), trade disruptions, financial instability, and human displacements (Sundin 2014). Better monitoring and prediction of climate change, better understanding of impacts on human and ecosystem health, etc. are examples of global benefits. Also, adaptation measures may prevent potentially huge climate-induced displacement, regarded as an indirect global benefit (Pickering and Rubbelke 2014).

Kartha (2008) identifies several global benefits of national adaptation, such as reduced vulnerability of trading partners, reduced dislocation and migration, reduced pressure for violent conflicts, etc. Such benefits may not be enjoyed equally by all countries and citizens, as tax-funded NPGs do not benefit all citizens equally, or some may not benefit at all. It may be recalled that achieving global social justice in an interdependent world was a central goal of President Roosevelt's New Deal in response to economic disruptions caused by the Great Depression. Achieving such a goal, Roosevelt argued at the opening of the Bretton Woods Conference in 1944, required a multilateral response: "Economic diseases are highly communicable, [i]t follows, therefore, that the economic health of every country is a proper matter of concern to all its neighbors, near and distant" (Roosevelt 1944). Climate change and Covid-19induced economic distress affecting all countries are examples of such communicability.

Finally, with evolving better knowledge of cross-border climate impacts and constructions of new and integrated knowledge across disciplines, time has come for articulation of adaptation in a trans-border trans-disciplinary way (Benzie and Persson 2019; Khan 2014). Banda (2018) rightly reconceptualizes adaptation as a multi-level PG, with domestic, transboundary, and global dimensions; he also explores the implications of this conceptual shift, proposing a multi-level governance model that could help produce what he calls "optimal adaptation." Seo (2013) argues for "smart adaptation" that can contribute to both adaptation and mitigation, as shared GPGs. Such a reconceptualization will sensitize the global community, facilitating to overcome the perennial risk of underprovision of GPGs, like adaptation. This expansive understanding by Kaul et al. (2003:185) is based on a multi-disciplinary

Table 1 Key types of adaptation benefits

\begin{tabular}{|c|c|c|c|}
\hline Local private benefits & Local public benefits & Direct global benefits & Indirect global benefits \\
\hline $\begin{array}{l}\text { Value of saved crops for } \\
\text { individual farmers, } \\
\text { improved water storage } \\
\text { for households, and } \\
\text { strong and resilient } \\
\text { housing }\end{array}$ & $\begin{array}{l}\text { Flood-proofed } \\
\text { infrastructure, } \\
\text { afforestation preventing } \\
\text { mudslides, coastal } \\
\text { afforestation as wind } \\
\text { and flood breaks, and } \\
\text { local water storage } \\
\text { facilities }\end{array}$ & $\begin{array}{l}\text { Control of } \\
\text { climate-sensitive in- } \\
\text { fectious disease, pro- } \\
\text { tection of } \\
\text { climate-sensitive } \\
\text { biodiversity, } \\
\text { agricultural research on } \\
\text { flood- and } \\
\text { saline-resistant crops, } \\
\text { and improved model- } \\
\text { ing of climate impacts }\end{array}$ & $\begin{array}{l}\text { Continuation of statehoods } \\
\text { by many SIDS, avoided } \\
\text { international migration, } \\
\text { lower price volatility on } \\
\text { climate-sensitive agri- } \\
\text { cultural products, and } \\
\text { enhanced purchasing } \\
\text { power among the vul- } \\
\text { nerable communities } \\
\text { and countries }\end{array}$ \\
\hline
\end{tabular}

Source: Adapted from Persson (2011) and expanded by the authors. 
framing, drawing from (1) theories of public goods, (2) theories of market failure, (3) theories of basic needs, and (4) political economy.

Together, our framing harvests ideas also from international law and relations, security studies, state responsibility, and so on. Attempting to integrate Banda's GPG levels, on the notion that both causes and effects (both direct and indirect) of climate change are GPBs, and addressing them both should be considered as GPG, bringing in global benefits and ensuring intra-and-intergenational equity is needed. However, just an esoteric reconceptualization of adaptation may not do, it warrants justifying the political salience for materializing this new norm in a global setting.

\subsection{The political salience of adaptation as a GPG}

Hall and Persson (2018) characterize the degree of legalization of adaptation governance under the UNFCCC as low in both obligation and precision. This reflects the continued struggle over the framing of adaptation between the developed and developing countries: while the former frame climate change merely as a technical problem to be solved through collaboration with low-carbon technologies, the latter frame it as additional burden to development, requiring global support for socio-economic and technical solutions (Hulme 2017).

In fact, climate change is among many stresses that define vulnerability, and it makes little sense to prioritize additionality in costs over the need to integrate adaptation into development policies. Klein (2010) argues that from an operational viewpoint, it makes "common sense" to integrate adaptation with development, but from a policy perspective it blurs adaptation finance with ODA. Actually, these two forms of funding are fungible, where recipient countries can realign their spending for an adaptation-development mix (Eyckmans et al. 2015). The development literature now talks more about climate-resilient development, to emphasize the link between adaptation and development (Fankhauser and Schmidt-Taub 2011; Stern 2009). Fankhauser and McDermott (2014) show that economic development affects both the supply and demand for adaptation. Now, developing countries support mainstreaming, but where is the new and additional, adequate, and predictable finance, as agreed under the regime? The share of climate finance in ODA is going up, to 26\% in 2018, from 18\% in 2013-2014 and 4\% in 2003-2004 (OECD-DCD 2015), but ODA is going down, and this appears to be a simple displacement of ODA. Kaul (2017c) laments that it is worrisome to watch the present "beauty competition" among development agencies, vying for being No. 1 in terms of taking climate finance out of ODA.

So the public discourse on adaptation governance and GPG framing for adequate financing is a political struggle across the "bordered" world, against the increasing cross-border flows of goods and services, capital, people, and risks. But GPGs have a normative and distributive connotation while contrasting with GPBs, and articulating an issue as a GP enhances its status and rhetorical value for wider response (Bodansky 2012). Long and Woolley (2009), critics of GPGs, also agree to its rhetorical value, and this is needed for political legitimacy and public acceptance of the norm of adaptation as a GPG. Actually, rhetorics have great contribution to shaping discourse in social science, intensifying the meaning of their elements and strengthening their argumentative power (Teixera 2015). So, we find some reconciliation between the supporters and critiques of GPGs.

Kaul (2013) further argues that a focus on GPGs indicates not only their "public" nature, but also their role in decision-making processes, ensuring procedural justice. Nye (2016) suggests that while the USA led in production of GPGs since WWII, now, cooperation of 
other powerful states is needed, because power has become a positive-sum game for achieving global goals. The GCA (2019) strongly urges all countries to initiate three revolutions: (a) a revolution in understanding of climate risks, making them visible; (b) a revolution in planning based on long term vision; and (c) a revolution in financing for adaptation. For all these revolutions to happen, a new kind of cooperative arrangement is needed, where the proposed norm of adaptation as a GPG can be the organizing principle.

However, at the policy level too, there are both supporters and critics. In the 2000s, the GPG debate was supported by the EU, while Japan and the USA opposed it. The central issue was the question of additionality of finance, above ODA. Developing countries feared ODA diversion into the provisioning of GPGs, and how their governance was undemocratic (Carbone 2007). The EU continues to support contributions based on ability to pay (i.e., GDP) and responsibility for GHG emissions (EC 2009). Sweden and France, regarded as pioneers in GPG promotion, established an International Task Force on GPGs in 2003. The Task Force defined GPGs as issues that are considered important to the global community, which must be addressed collectively (cited in Carbone 2007). The Task Force identified among others tackling climate change as a GPG. The study included strategies such as strengthening adaptive capacity in developing countries. As negotiators under the UNFCCC, the authors testifies that capacity building as a GPG is not contested, discussed under Article 11 of the Paris Agreement.

So, with an approach of cognitive flexibility and frame-bridging across disciplines and policy arenas, we use three levers to raise adaptation framing at a higher strategic plane (Khan and Roberts 2013). The first lever is "double exposure" causing double loss to the PVCs due to their simultaneous exposure to market-led uneven globalization and climate change (Liechenko and O'Brien 2008). Today, most of the developing countries suffer from triple distresses: Covid-19, unbearable debt burden, and increased L\&D from climate impacts, which are pushing most of the PVCs further down the spiral (HBS 2020). PVCs number over 100: 43 SIDS, 47 LDCs and a number of other countries including non-LDCs like Zimbabwe, Bolivia, the Philippines, Nicaragua, Pakistan, and India as low-middle income countries. India alone has $18 \%$ of the global population. When the PVCs benefit from strengthening their economies and adaptive capacities, other countries also will benefit. Rightly, a number of policy partnerships involving public and private sectors in the 2019 Climate Action Summit have been announced, including Climate Change Resilience Investment, the Africa Adaptation Initiative, a Riskinformed Early Action Programme, a Call for Action (CAS (Climate Action Summit 2019). The Global Resilience Partnership, the Race for Rural Resilience Initiative under FAO, and many other movements have been initiated as well. Like the Race to Zero, there is the Call for a Race to Resilience: Raising Ambition for Climate Adaptation and Resilience, which has been endorsed by 118 countries and 86 organizations. These are timely steps in globalizing adaptation responsibility, slowly internalizing the new GPG norm as the organizing theme for action.

The second lever is the threat to human and global security from increasing climate impacts, both national and cross-border. Many countries are likely to face both direct and indirect threats to human and national security, which as a "threat multiplier" will snowball and spill over beyond national borders and onto the backyards of industrial countries (CAN 2007; Bernauer et al. 2012; Detraz 2011; Banda 2018). Oxfam (2018) indicates that people in poorer countries are on average five times more likely than people in rich countries to be displaced by extreme weather events. Where will they move, either internally, pushing others further into poverty, fuelling resource conflicts and political instability? Or, trying to move elsewhere through human traffickers, sometimes dying "watery deaths" or from other exposures? 
Lord Stern cogently and simply argued this point. "To say we cannot afford it [climate finance] is nonsense," he said, emphasizing that the returns from climate security compare very favorably with security benefits from external threats provided by defense budgets, which typically run at ten times the amount needed for reaching a climate deal (just $1 \%$ of the global GDP). Stern concluded that "the claim 'we cannot afford it' is not very different from 'we are not sufficiently bothered to deal seriously with climate change' ... [and] that is simply reckless" (Stern 2009: 179). So, interest from security establishments in climate risks and in analyzing policy options are rising globally (World Economic Forum 2019). Actually, the main solution lies in ensuring adaptation-focused human security in situ from increasing vulnerabilities.

The third lever is the rights-and-justice framework. The low-income countries are being hit first and hardest as innocent victims, with nano contributions to the problem. So this must be grounded on rights and justice claims that the right to "no harm" is an inalienable right, established and codified in international law, and being practiced in many parts of the world. Many scholars argue that climate impacts documented by the IPCC are already undermining and likely to further undermine the realization of a range of protected human rights - right to life, liberty, security, and livelihoods (Caney 2010; Shue 1999). Now, there is a growing interest among diverse stakeholders including the corporate sector in adaptation governance, and this indicates a shift from its earlier "depoliticized" and "technocratic" approaches to one of greater political contestation (Remling 2018).

Actually, political support for global externality management is growing stronger. Being "green" is a response by companies to increasing green consumerism, and it is also a matter of corporate prestige. The World Business Council for Sustainable Development in a recent policy paper (WBCSD, 2019) strongly supports introducing carbon pricing, which they see as providing policy certainty and enhancing competitiveness. An increasingly informed public, more climate-friendly businesses, the growth of transnational civil society, and increasing public-private partnerships are facts of a globalized world. Given intensely growing pressure at all levels, the possibility of extra-budgetary resources for climate finance does not appear farfetched.

\section{Adaptation as a GPG would make a difference in funding}

\subsection{Additional finance for adaptation}

Recognition of adaptation as a GPG will require additional money. The $\$ 100$ billion pledge by 2020 is far below the need. Addressing borderless risks is likely to divert more climate finance or ODA from national-level actions. Kaul et al., 2003, Kaul, 2017c) argue that GPG financing must not jeopardize ODA since it is needed for basic provisions in poor countries, while the supply of GPGs can contribute to resilience to climate impacts and poverty reduction (Kaul 2013). So the Paris Agreement (Article 9.3) provides that "developed country Parties should take the lead in mobilizing climate finance from a variety of sources, instruments, and channels, noting the significant role of public funds ..."

Since the 1990s, a new thinking has emerged that GPGs should be financed by resources other than ODA (Carbone 2007; Kaul et al. 2003; Kaul 2017a, 2017c). Despite the support of many EU countries on GPG financing, this idea could not proceed much because of opposition from Japan and the USA. Some major EU countries already contribute $0.7 \%$ or more of their 
GNI as ODA, while others remain well below that level. Achieving the $0.7 \%$ target could mobilize an additional $\$ 200$ billion a year. But a recent UK decision to reduce ODA to $0.5 \%$ of their GNI is discouraging. Though trillions were mobilized as stimulus packages at short notice to rescue developed economies from the fallout from Covid-19, it is exceedingly unlikely their generosity will match the assumed obligations for adaptation finance. So there are new ideas of mobilizing additional money, through debt for climate swaps, climate bonds, enhanced insurance schemes, airline taxes, etc. (HBS 2020; Khan 2020).

How can we mobilize additional funding and overcome the theoretical and institutional lock-in to which climate finance remains hostage? Many proposals have been discussed over the last decade. At the 2019 Climate Action Summit, many proposals came in, including proposals of a carbon tax, phasing out fossil fuel subsidies, a financial transaction tax, and carbon pricing for international aviation and shipping. The EU is a strong advocate of imposing a levy on these last two sources, as their international emissions, about $2 \mathrm{GtCO}_{2} \mathrm{e} /$ year (UNEP 2020) are not covered in the NDCs.

Already France leads an initiative on a financial transaction tax, along with some other EU members, which is distributed as climate finance. Actually, it does not matter whether additional money is mobilized domestically or internationally, because the internalization of externalities, even cross-border ones, begins at home. Essentially, GPGs amount to national public goods plus international cooperation. Given growing pressure globally at public, civil society, and development agency levels, any future possibility of mobilizing extra-budgetary resources cannot be ruled out. Pittel and Rübbelke 2013rightly argue that enhanced adaptation finance may induce developing countries to undertake more mitigation, which is a universally agreed GPG and is the ultimate solution to climate change. Large-scale mitigation investments could significantly limit the costs of global adaptation.

However, the pivotal instrument having the highest potential of generating public climate finance is the polluter-pays-principle (PPP), which is implicit in the Convention principle of CBDR+RC. Those polluters should pay the social and environmental costs of pollution to reflect the most fundamental lessons of economics, justice, and responsibility. Is it not the very foundation of the regime, as argued before, and its extension into emissions trading, based on cost effectiveness? While terrestrial landfills are not free, why should atmospheric dump be treated as free (Young 2010)?

The PPP originated as an economic and ethical principle, gradually evolving into a legal one, codified in the EU and elsewhere (Khan 2015). The cardinal principle of CBDR+RC can be operationalized most effectively through the global application of PPP through carbon pricing, factoring in historical responsibility for causing the problem (Khan 2017; Seo 2013). The PPP is also practiced in several developing countries, such as Taiwan, Chile, and South Africa (Luppi et al. 2012). It has both efficiency and equity elements, deserving global adoption (Nash 2000). The non-internalization of externalities by major emitters at this point in our knowledge about the causes of climate change is genuine free-riding (Khan 2014).

Falling fossil fuel prices and renewable energy options give an opportunity for carbon pricing, which can provide a source of much-needed funds. The G20 pledge of eliminating fossil subsidies back in 2009 has still not yet been realized, even though the G7 2021 recommitted to do so. Almost half a trillion dollar of yearly subsidy to fossil fuels worldwide actually funds the climate problem, not the solution. The 2019 Climate Summit unequivocally demanded for carbon pricing and removal of fossil fuel subsidy, as the Secretary General himself very forcefully argued for taxing pollution, not people. Already about 57 carbon pricing programs at the local, national or international levels are being implemented across the 
world (World Bank 2019). However, the price range varies widely, with the highest being in Sweden with its price of $\$ 126 /$ ton. By contrast, Poland and Ukraine have imposed prices just above zero, while the same source estimates the social cost of carbon is $\$ 52 /$ ton. Even with half its price per ton, more than a trillion dollar could be mobilized a year beyond the public treasuries each year.

Thus, a carbon price applied initially to the G20 economies can generate adequate and predictable money for building a low carbon climate-resilient world. To ensure equity, there can be a differentiated application among countries, what Caney (2010) calls "povertysensitive" PPP. Actually, carbon taxes can be paired with "carbon dividends" for the poor. The development agencies led by the World Bank, issue networks, businesses, and CSOs/ NGOs have growing clout in the discourse on carbon pricing. Now, the consent of Japan and the new US administration may help realize the additionality in climate finance. Upon its acceptance, institutional mechanisms can be further negotiated.

\subsection{The role of multilateral institutions in promoting adaptation as a GPG}

Post-Paris climate governance has become more polycentric, more bottom-up as a multi-actor affair (Jordan et al. 2018). Taking an institutionalist's perspective, we argue that it strongly matters whether new norms are first accepted and embedded in international institutions, since they are considered as "a force in global politics" (Khan 2016:16). So, as a follow-up to UNDP initiatives on GPGs of the last decades, the World Bank has commissioned the study Collective Solutions 2025 as a collaborative platform, to understand, among other things, its role in GPG provision (World Bank 2012). Birdsall and MacDonald (2013) propose to create a new arm of the World Bank to deal with climate change, but this proposal needs further scrutiny.

The climate regime-related institutions, such as the GEF, the Adaptation Fund, and the LDC Expert Group, are already considering transboundary risks in adaptation actions (cited in Banda 2018). The GCF has the potential to play a stronger role in adaptation as the largest climate fund. Its Board already has decided to allocate half of the climate finance to both adaptation and mitigation, with an aim of delivering 50\% of adaptation money to the PVCs. However, the GCF handles a quite small share of climate money. Still, this suggests a potential paradigm shift toward a transformative adaptation as a new norm. This shift calls for the increasing provision of funds for national public goods and GPGs, which reinforce one another.

National public goods are funded mostly by governments, and so is the expectation from developing country negotiators, as the Paris Agreement Article 9.3 emphasizes the importance of public finance. Because of developing countries' pressure, the GEF has broadened its understanding of global benefit, and funded a number of adaptation projects. In recent times, both the GCF and the GEF are increasing funding for regional and global projects on both adaptation and mitigation, including resilience-building in marine environments.

Now, a consensus has emerged that low-carbon and climate-resilient development is key to solving the most intractable problem, as evidenced by the GCF Governing Instrument (para 12). The Paris Agreement Article 2.1c explicitly links achieving this goal with the level of financing. It also rightly linked the need for adaptation with the level of mitigation (Article 7.4). In view of this renewed focus on adaptation and its expansive governance space, agencies such as the World Bank, UNDP, UNEP, UNFCCC, the GEF, and GCF have the potential collectively to set new norms, including the expanded GPG framing of adaptation.

Historically, the UN agencies played the role of 'norm entrepreneurs' (Chasek et al. 2010). For example, UNDP initiated the human development index and the norm of human security in the mid- 
1990s. As "knowledge brokers," multilateral organizations may circumvent the principal-agent relationship, and influence state behavior. Kaul (2017a, 2017c) advocates for a stronger role of MDBs for the provision of GPGs, suggesting that the MDBs could keep funds dedicated for GPGrelated purposes separate from funds for national projects. She also suggested the creation of a separate institution like the OECD-DAC to handle GPG fund mobilization.

Enhancing the role of MDBs is more feasible where there is a wide diversity in views among major powers, as on climate finance. So a stronger network of UNFCCC Parties, UN agencies, MDBs, and civil society can continue putting pressure for additionality and adequacy in climate finance, with the application of the Polluter Pays Principle. An increasing number of transnational organizations, civil society, and corporate actors are now active players articulating transboundary climate risks and in defining adaptation governance (Persson and Dzebo 2019; TCFD 2017).

\section{Conclusion}

In line with Einstein's dictum that no problem can be solved with the same level of consciousness that created it, this article attempts a reframing of adaptation and its financing. The recognition of adaptation as a global responsibility and adoption of a global goal under the Paris Agreement, though sounds vague, is a step forward. This is an era of increasing GPG issues arising in the global commons, and new conceptualizations, different from neoclassical and national territory-bounded lenses, are needed. Accordingly, with an approach of cognitive flexibility and frame-bridging, we have tried to conceptualize adaptation as a GPG against climate impacts, which are a GPB. The GPB of climate change has its universal but varied effects on countries and populations; these have direct and indirect effects across boundaries and around the globe.

Despite having agreed provisions to consider expanded responsibility for climate adaptation, these are not yet respected by many of the powers that be. An expanded view of adaptation benefits requires a changed perspective of sovereignty; power and national interests may induce nations toward an obligatory responsibility of financing adaptation in the PVCs. As a policy domain, adaptation is socially defined and socially constructed. So, it begs to be considered with multi-disciplinary and multi-focal lenses. Such framing is expected to raise its status on the global policy plane, thereby making a difference in boosting finance. The application of the Polluter Pays Principle in varied forms, both nationally or internationally, serves as the key to such a policy design. Even tax-funded national public goods do not benefit all citizens equally, and some may not benefit at all. Adequate support for climate adaptation may encourage developing countries to go for higher mitigation. The global stock-take under Article 7.14 of the PA in 2023 will be a turning point in realizing these ideas. We believe this discourse will surely be contested in the policy and discursive world, and that is the ultimate purpose of this article.

Code availability No software used

Authors' contributions First author contributed more, but co-author also contributed significantly

Data availability Not applicable 


\section{Declarations}

Ethics approval Not applicable

Consent to participate Not applicable

Consent for publication Authors consent for the publication of the manuscript

Conflict of interest No conflict of interest

\section{References}

Abadie LM, Galarraga I, Rübbelke D (2013) An analysis of the causes of the mitigation bias in international climate finance. Mitig Adapt Strateg Glob Chang 18(7):943-955

Ayers J (2011) Resolving the adaptation paradox: exploring the potential for deliberative policy-making in Bangladesh. Global Environ Polit 11(1):62-88

Banda ML (2018) Climate adaptation law: governing multi-level public goods across borders. Vanderbilt J Transl Law 51:1027-1074

Barrett S (2008) Climate treaties and the imperative of enforcement. Oxf Rev Econ Policy 24(2):239-258

Benzie M, Persson $\AA$ (2019) Governing borderless climate risks: moving beyond the territorial framing of adaptation. Int Environ Agreements: Politics, Law and Economics 19(4-5):369-393

Bernauer T, Bohmelt T, Kouvi V (2012) Environmental changes and violent conflict. Environ Res Lett 7(1):108

Best J (2008) Ambiguity, uncertainty, and risk: rethinking indeterminacy. Int Polit Sociol 2(4):363

Birdsall, N., \& De Nevers, M. (2012). Adaptation finance. How to Get Out from between a Rock and Hard Place. CGD Policy Paper, 1.

Birdsall N, MacDonald L (2013) Wanted: a climate agency for a bottom-up world: a proposal for a new arm of the World Bank. Center for Global Development, Washington

Bodansky D (2012) What's in a Concept? Global Public Goods, International Law, and Legitimacy. Eur J Int Law 23(3):651-668

Buchner B, Clark A, Falconer A, Macquarie R, Meattle C, Wetherbee C (2019) Global Landscape of Climate Finance 2019, Climate Policy Initiative.

Burton I (2009) Climate change and the adaptation deficit. In: Schipper L, Burton I (eds) The Earthscan Reader on Adaptation to Climate Change. Earthscan, London

CAN (Center for Naval Analysis) (2007) National security and the threat of climate change. CAN Corporation, Alexandria

Caney S (2010) Climate change and the duties of the advantaged. Crit Rev Int Soc Pol Phil 13(1):203-228

Carbone M (2007) Supporting or resisting global public goods? The policy dimension of a contested concept. Glob Gov 13:179-198

CAS (Climate Action Summit, 2019). Report of the Secretary General on Climate Action Summit 2019, New York.

Chan S, Amling W (2019) Does orchestration in the Global Climate Action Agenda effectively prioritize and mobilize transnational climate adaptation action? Int Environ Agreements: Politics, Law and Economics. https://doi.org/10.1007/s10784-019-09444-9

Chasek PS et al (2010) Global Environmental Politics, 5th edn. Westview Press, Boulder

DeSombre ER (2000) Developing country influence in global environmental negotiations. Environ Polit 9(3):23-42

Detraz N (2011) Threats or vulnerabilities? Assessing the link between climate change and security. Global Environ Polit 11(3):104-120

Development Tracker Insights (2020). Financing for the future: climate finance and the role of ODA, 03 August. Available at: https://donortracker.org/insights/financing-future-climate-finance-and-role-oda.

Driesen DM (ed) (2009) Economic thought and US climate change policy. MIT Press, Cambridge

Dzebo A, Stripple J (2015) Transnational adaptation governance: an emerging fourth era of adaptation. Glob Environ Chang 35(November):423-435. https://doi.org/10.1016/j.gloen

European Commission (2009) Stepping up international climate finance: a European blueprint for the Copenhagen deal, Brussels. COM 2009:475/3

Eyckmans J, Fankhauser S, Kverndokk S (2015) Development aid and climate finance. Environ Resour Econ 63(2):429-450 
Fankhauser S, McDermott T (2014) Understanding the adaptation deficit: why are poor countries more vulnerable to climate events than rich countries? Glob Environ Chang 27:9-18

Fankhauser S, Schmidt-Taub G (2011) From adaptation to a climate resilient development. Clim Dev 3(2):94 113

Farber DA (2007) Basic compensation for victims of climate change. Univ Pa Law Rev 155:16051656

Gardiner SM (2006) A perfect moral storm: intergenerational ethics and the problem of moral corruption. Environ Values 15:397-413

GCA (2019) Adapt Now: A Global Call for Leadership in Climate Resilience. The Netherlands, Amsterdam

Haas P, Keohane R, Levy M (2003) Institutions for the Earth: Sources of Effective International Environmental Protection. MIT Press, Cambridge

Hall N, Persson $\AA$ (2018) Global climate adaptation governance: why is it not legally binding? Eur J Int Relat. https://doi.org/10.1177/1354066117.725157

Hedlund J, Fick S, Carlsen H, Benzie M (2018) Quantifying transnational climate impact exposure: new perspectives on the global distribution of climate Risk. Glob Environ Chang 52(September):75-85

Heinrich Boll Stiftung (HBS) (2020), Debt Relief for Green and Inclusive Recovery, Berlin.

Hulme M (2017) Weathered: cultures of climate. Sage, London

IPCC (2018) Summary for policymakers. Global warming of $1.5^{\circ} \mathrm{C}$. World Meteorological Organization, Geneva

Jordan A, Huitema D, Van Asselt H, Forster J (eds) (2018) Governing climate change: polycentricity in action? Cambridge University Press, Cambridge

Kartha S (2008) Adaptation as a strategic issue for the climate change negotiations. In: Egenhofer C (ed) Beyond Bali: Strategic Issues for the Post-2020 Climate Change Regime. Brussels, The Centre for European Policy Studies

Kaul I (2013) Global public goods: a concept for framing the post-2015 agenda, Discussion Paper, German Development Institute, DIE.

Kaul I (2017a). Putting climate finance into context: a global public goods perspective. In: Markandya, A., I. Galarraga and D. Rübbelke, eds. Climate Finance. World Scientific Publishers, pp. 129-156.

Kaul I (2017b). Presentation at the German Development Institute (DIE), Bonn, 24 January 2017. Available at: https:/www.google.com/search?q=Providing+Global+Public+Goods\%3A+The+Role+for+the+G20\&rlz= 1C1CHBF_enUS815US815\&oq=Providing+Global+Public+Goods\%3A+The+Role+for+the+G20\&aqs = chrome..69i57.2877j0j7\&sourceid=chrome\&ie=UTF-8. Accessed 15 Mar 2019.

Kaul I (2017c) Providing for global public goods: the role of multilateral development banks. Overseas Development Institute, London

Kaul I, Grunberg I, Stern MA (eds) (1999) Global public goods: international cooperation in the $21^{\text {st }}$ century. Oxford University Press, New York

Kaul I, Conceicao P, Goulven K, Mendoza R (eds) (2003) Providing global public goods: managing globalization. Oxford University Press, New York

Kenny C (2020) Official development assistance, global public goods and implications for climate finance. Centre for Global Development, Washington

Khan MR (2014) Toward a binding climate change adaptation regime. Routledge, London

Khan MR (2015) Polluter-Pays-principle: the cardinal instrument for addressing climate change. Laws 4(3):638653

Khan MR (2016) Climate change, adaptation and international relations theory. In: Atkins E, Sosa-Nunez G (eds) Environment, climate change and international relations. E-International Relations Publishing, Bristol, pp 14-28

Khan MR (2017) Right to development and historical emissions: a perspective from the particularly vulnerable countries. In: Meyer L, Sanklecha P (eds) Climate Justice: The Relevance of Historical Emissions. Cambridge University Press, Cambridge

Khan M.R (2020). Debt for adaptation swap - investment in adaptation and resilience. Mimeo. Berlin, London, and Boston: Debt Relief for Green and Inclusive Recovery Initiative, Heinrich Boll Stiftung.

Khan MR, Roberts JT (2013) Adaptation and international climate policy. Wiley Interdiscip Rev Clim Chang 4(3):171-189

Klein, R. J. (2010). Mainstreaming climate adaptation into development: a policy dilemma. Clim Govern Dev 35. Liechenko RM, O’Brien K (2008) Environmental change and globalization. Oxford University Press, Oxford Long D, Woolley F (2009) Global public goods: critique of a UN discourse. Glob Gov 15:107-122

Luppi B, Parisi F, Rajagopalan S (2012) The rise and fall of the polluter-pays principle in developing countries. Int Rev Law Econ 32:135-144

Magnan AK, Ribera T (2016) Global adaptation after Paris. Science 352(6291):1280-1282. https://doi.org/10. 1126/science.aaf5002 
Michaelowa, A. (2001). Mitigation versus adaptation: the political economy of competition between climate policy strategies and the consequences for developing countries, HWWA Discussion Paper 153, Hamburg Instit Intern Econ.

Nakhooda S et al (2013) Mobilizing international climate finance: lessons from the fast start finance period. World Resources Institute, Washington

Nash J (2000) Too much market? Conflict between tradable pollution allowances and the polluter pays principle. Harvard Environ Law Rev 24(465):1-59

Netherlands Environmental Assessment Agency (2011) A global public goods perspective on environment and poverty reduction. Implications for Dutch foreign policy, The Hague

Nordhaus WD (2005) Paul Samuelson and Global Public Goods. A commemorative essay for Paul Samuelson. Yale University.

Nye J (2016) Politicians say American leadership is in decline: they are wrong,' op.ed. The Washington Post, 29 January 2016.

OECD (2020). Climate Finance Provided and Mobilized by Developed Countries in 2013-18: Key Highlights. Paris.

OECD/DCD (Organization for Economic Cooperation and Development/ Development Cooperation Directorate). (2015). Climate-related development finance in 2013-14.Paris: OECD. Available at https:// www.oecd.org/dac/environment-development/Climaterelated-dev-finance-ENG.pdf/ -accessed 24/04/2016.

Okereke C (2010) Climate justice and the international regime. Wiley Interdiscip Rev Clim Chang 1(3):462-474

Oxfam (2012) The climate fiscal cliff: an evaluation of fast start finance and lessons for the future. Oxfam Media Advisory, Oxford

Oxfam (2018) Climate Finance Shadow Report 2018. UK, Oxford

Oxfam (2020). Climate Finance Shadow Report, Oxford.

Persson, $\AA$ (2011) Institutionalising climate adaptation finance under the UNFCCC and beyond: could an adaptation "market" emerge. Stockholm Environemnt Institute, Working Paper, (2011-03).

Persson, A. (2019). Global adaptation governance: an emerging but contested domain, WIREs Climate Change, pp. 1-18.

Persson A, Dzebo A (2019) Editorial, Special issue: exploring global and transnational governance of climate change adaptation. Int Environ Agreements: Politics, Law and Economics 19:357-367

Pickering J, Rubbelke D (2014) International cooperation on adaptation to climate change. In Routledge Handbook of the Economics of Climate Change Adaptation (pp. 56-75). Routledge.

Pittel K, \& Rübbelke DT (2013). Improving global public goods supply through conditional transfers-The International Adaptation Transfer Riddle.

Rayner S \& Malone EL (1998). The challenge of climate change to social sciences. In: S. Raynerand, E. L. Malone (eds). Human Choice and Climate Change: An International assessment. Vol.4: What Have We Learned? Columbia, OH: Battelle Press.

Remling E (2018) Depoliticizing adaptation: a critical analysis of EU climate adaptation policy. Environ Polit 27(3):477-497

Roosevelt FD. (1944). Department of State (Ed.). United Nations Monetary and Financial Conference: Bretton Woods, final act and related documents, New Hampshire, July 1 to July 22, 1944. Washington, DC: United States Government Printing Office.

Samuelson P (1954) The pure theory of public expenditures. Rev Econ Stat 36:387-389

Sandmo A (2006) Global Public Economics: Public Goods and Externalities.' Économie publique/Public economics [En ligne], 18-19 |1-2, Available at: http://economiepublique.revues.org/4282 (accessed 05 March 2016)

Seo SN (2013) Economics of global warming as a global public good: private incentives and smart adaptations. Reg Sci Policy 5(1):83-95

Shue H (1999) Global environment \& international inequality. Int Aff 17(3):531-545

Stern N (2008) The economics of climate change. Am Econ Rev 98:1-37

Stern N (2009) The global deal: climate change and the creation of a new era of progress and prosperity. Public Affairs, New York

Stiglitz J (2012) The price of inequality. W.W. Norton, New York

Sumner A (2012) Where do the poor live? World Dev 40(5):865-877

Sundin A (2014). Conceptual framework for assessing indirect impacts of climate change, weADAPT, last updated 23 Oct. 2020. Available at: https://www.weadapt.org/knowledge-base/transnational-climateimpacts/conceptual-framework-for-assessing-indirect-impacts-of-climate-change. Accessed 15 Mar 2020

TCFD (2017) Final report: recommendations of the task force on climate-related financial disclosures. TCFD https://www.fsb-tcfd.org/wp-conte nt/uploads/2017/06/FINAL-TCFD-Report-062817.pdf. Accessed 15 Mar 2020

Teixera L (2015). Rhetorics and discourse studies, Bakhtiniana, São Paulo, 10 (3): 113-122. 
Tigre MA (2019) Building a regional adaptation strategy for Amazon countries. Int Environ Agreements: Politics, Law and Economics. https://doi.org/10.1007/s10784-019-09443w

UNEP (2016) The adaptation finance report: a preliminary assessment, Nairobi.

UNEP (2020). Emissions Gap Report 2020. Available at https://www.unenvironment.org/emissions-gap-report2020. Accessed 10 Dec 2020

UNFCCC (2016) Aggregate effect of the intended nationally determined contributions: an update. UNFCCC Secretariat, Bonn

Vanderheiden S (2011) Globalizing responsibility for climate change, ethics and international affairs, 25(01): 6684.

Verheyen R (2005) Climate change damage and international law: prevention, duties and state responsibility. Martin-Nijhoff Publishers, Leiden/Boston

WBCSD. (2019). Climate Action and Policy. Retrieved from World Business Council for Sustainable Development : https://docs.wbcsd.org/2019/09/Carbon-Pricing-WBCSD-Policy-Paper-2019.pdf. Accessed 10 Mar 2020

Weikmans R, Roberts JT, Baum J et al (2017) Assessing the credibility of how climate adaptation aid projects are categorized. Dev Pract 27:458-471

World Bank (2012) Your World Needs You. Solutions for 2025. Retrieved from World Bank: https://blogs. worldbank.org/voices/your-world-needs-you-solutions-for-2025. Accessed 2 Februar 2020

World Bank (2019) State and trends of carbon pricing 2019. World Bank Group, Washington

World Bank (2020) Poverty and shared prosperity 2020: reversals of fortune. World Bank, Washington

World Economic Forum (2019) The global risks report 2019, 14th edn. WEF, Geneva

Wuyts M, Mackintosh M, Hewitt T (1992) Development policy and public action. Oxford University Press in association with the Open University, Oxford

Young O (2010) Institutional dynamics: emerging patterns in international environmental governance. The MIT Press, Cambridge

Zedillo E (ed) (2008) Global warming: looking beyond Kyoto, Washington, DC: Center for the Study of the Globe, Yale University; Brookings Institution Press.

Publisher's note Springer Nature remains neutral with regard to jurisdictional claims in published maps and institutional affiliations. 